\title{
Evidence that the Vinland Map Was Drawn Using an Iron Gall Ink: The Continuing Need for Further Research
}

\author{
Jacqueline S. Olin \\ Great Falls, USA \\ Email: jacqueolin1@aol.com
}

Received August 20, 2012; revised September 22, 2012; accepted October 3, 2012

\begin{abstract}
The Vinland Map is a map of the world that shows "the island of Vinland" in the northwest Atlantic Ocean. It is housed in the Beinecke Rare Book and Manuscript Library at Yale University. The Map has been purported to date from the Council of Basle, AD 1431-1449. The nature of the ink of the Map has not been identified. It has been suggested that it may be an iron gall ink, a carbon ink or an ink that contains anatase and gelatin and perhaps other unknown constituents. This paper will present evidence that supports the ink being an iron gall ink. It is intended that this evidence will encourage further research.
\end{abstract}

Keywords: Iron Gall Ink; UV Examination of Iron Gall Ink; Iron Gall Ink Corrosion

\section{Introduction}

The controversy surrounding the Beinecke Library's Vinland Map was originally based on cartographic questions regarding whether it was possible that this map was drawn at the time proposed by the authors of the Yale University Press publication, The Vinland Map and the Tartar Relation [1]. At the time of publication in 1965, the proposal that the Map had been drawn in the first half of the 15th century and showed evidence of lands known to be in the North Atlantic prior to Columbus was indeed a cause of controversy. Then in 1974, Walter C. McCrone Associates, Inc. published the results of their study of the ink of the Vinland Map and declared that the ink contains anatase titanium dioxide and that it was present as a pigment that had not been produced until the early 20th century. This prompted Yale University to identify the Vinland Map as a forgery.

In 1974, another publication supported the attribution of forgery to the Vinland Map. This publication was based on examination of the Vinland Map at the Research Laboratory of the British Museum. A report of that examination follows:

The behavior of the ink under ultra-violet light was of particular interest. Iron compounds quench the fluorescence induced in the background by ultra-violet light and for this reason, faded iron gallo-tannate ink, yellowish-brown by daylight, will appear black against a bluish or yellowish fluorescent background under this form of lighting. The inks used in both the Tartar Relation and the Speculum Historiale showed this phenomenon whereas the ink used both for the outline of the map itself and for the text on the leaf did not show this phenomenon $[2,3]$.

The observations made at the Research Laboratory of the British Museum and published in 1974 are found on the Ohio State University website [4]. Although the website suggests that the image published by Douglas McNaughton in his paper in Vikings: The North Atlantic Saga shows the Map as it would appear under ultraviolet, the McNaughton paper does not identify how the photograph was made [5]. No one has published an identified ultraviolet photograph taken of the Vinland Map that shows the image that resulted from exposure of the Vinland Map to ultraviolet radiation. The description of what was observed in the Research Laboratory that is given above is the information we have. It is not clear whether the lack of absorption of ultraviolet fluorescence was over the entire surface of the Map or rather on much of the surface. This is not explained. A currently prepared image taken of the Vinland Map under ultraviolet light would be valuable to include in the discussion.

\section{Review of Research on UV Examination of Iron Gall Inks}

At this point, it is useful to investigate the literature on the examination of iron gall inks using ultraviolet radiation. In a paper by Keith R. Knox and Roger L. Easton, Jr. titled, "Recovery of Lost Writings on Historical Manuscripts with Ultraviolet Illumination", there is a discussion of examination of the colophon of a Hebrew Prayer Book that was erased by the mechanical process of scraping the 
ink from the parchment [6]. Traces of the writing on the colophon are still visible; however, nothing legible is visible. However, according to the account of Knox and Easton, the scholars who viewed this page with ultraviolet "reported that no characters were visible". Knox and Easton conclude that the ink removal may have resulted in a surface where there was nothing to affect the ultraviolet fluorescence of the parchment. It is very important to consider that the reason the Baynes-Cope did not observe the black appearance of the ink on examination of the Vinland Map that had been observed in the examination of the Tartar Relation and the Speculum Historiale had an explanation other than that it is not an iron gall ink. Might it not have been that in the case of the Vinland Map the ink had not been scraped off in areas but rather had flaked off? This would leave no iron in the ink in those areas to quench the fluorescence coming from the parchment thus giving an appearance unlike that normally observed with an iron gall ink.

\section{Evidence That Supports Flaking of Ink from Vinland Map}

It is important now to research the literature regarding the Vinland Map to determine if there is evidence that the ink of the Map did flake off. One bit of evidence can be found in Walter McCrone's report to Yale University Library in 1974 and titled, "Chemical Analytical Study of the Vinland Map" [7].

In the McCrone Report under Table 2, Summary of Microanalytical Data there are data for Slide A, Loose particles from map crease. These data are: size 100 microns, black, grainy (artifact?) and under the column labeled "Anatase" is the phrase "not obs". There are no $\mathrm{X}$-ray diffraction data published in the Report. However in the column under $\mathrm{X}$-ray Diffr $^{\mathrm{n}}$ for Slide $\mathrm{A}$, the particles are identified as $\mathrm{Fe}_{2} \mathrm{O}_{3}+\mathrm{FeO}(\mathrm{OH})$. The report does not discuss how many loose particles were found and, of course, particles could have been lost over time. It is important, however, to realize that the iron in the particles could have come from iron in the ink of the Map. Although it is important to investigate further whether there is other evidence of flaking iron gall ink that has produced $\mathrm{Fe}_{2} \mathrm{O}_{3}+\mathrm{FeO}(\mathrm{OH})$, it is useful to note that the author has found data in the literature for the "Formation of goethite by oxidative hydrolysis of iron (II) sulphate" [8]. We should not ignore the presence of iron in particles from the map crease in our consideration of whether or not the ink of the Map is an iron gall ink.

The presence of iron in the ink of the Map is confirmed by the analysis of the ink done by Thomas Cahill et al. [9,10] and by Walter McCrone [11]. It is the amount of ink that differs from other iron gall inks not that iron is not present. McCrone's data for iron are dis- cussed in the next section.

The table below (Table 1), is a compilation of X-ray diffraction data for samples of ink taken from the Vinland Map and presented by McCrone as Table III [10]. X-ray diffraction data for the particles from the crease which were identified as containing goethite were not included in McCrone's published data and the x-ray diffraction data for these samples were not included in the Report to Yale [6].

Table 1. X-ray diffraction data: (a) VM ink samples and anatase; (b) Calcite and quartz.

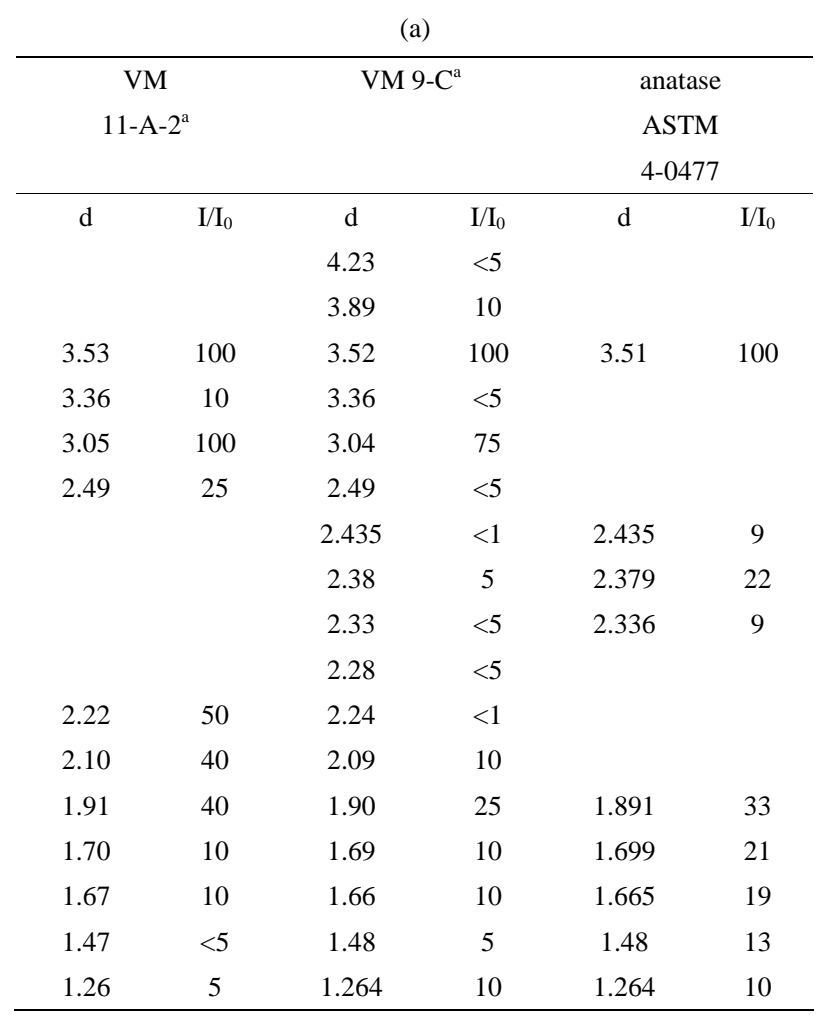

(b)

\begin{tabular}{|c|c|c|c|}
\hline \multicolumn{2}{|c|}{ calcite } & \multicolumn{2}{|c|}{ quartz } \\
\hline \multicolumn{2}{|c|}{ ASTM } & \multicolumn{2}{|c|}{ ASTM } \\
\hline \multicolumn{2}{|c|}{$5-0586$} & \multicolumn{2}{|c|}{$5-0490$} \\
\hline \multirow[t]{2}{*}{ d } & $\mathrm{I} / \mathrm{I}_{0}$ & d & $\mathrm{I} / \mathrm{I}_{0}$ \\
\hline & & 4.26 & 35 \\
\hline \multirow[t]{2}{*}{3.86} & 10 & & \\
\hline & & 3.34 & 100 \\
\hline 3.04 & 100 & & \\
\hline \multirow[t]{2}{*}{2.50} & 14 & & \\
\hline & & 2.46 & 12 \\
\hline 2.29 & 18 & 2.28 & 12 \\
\hline 2.10 & 18 & & \\
\hline 1.91 & 17 & & \\
\hline
\end{tabular}

${ }^{\mathrm{a}} 12$ - $16 \mathrm{~h}$ exposures with unfiltered $\mathrm{Cu}$ X-rays; $42 \mathrm{kV}$ and $34 \mathrm{~mA}$ with a 28.65-mm camera. 


\section{Summary of Evidence to Date on Nature of Vinland Map Ink}

The identification of carbon in the ink of the Vinland Map using Raman spectroscopy has been reported [12]. This point has been used as evidence that the Vinland Map ink is not an iron ink and the composition of the Map ink has been compared to that of the Tartar Relation in that regard. It is important to note that in Walter McCrone's 1988 paper his table of Comparative Ion Probe (IMA) Analyses of VM, TR, and SH Ink Samples, shows iron as $1 \%-5 \%$ in the ink of the TR and $\mathrm{SH}$ and greater than 5\% in the ink of the Vinland Map. In 2003, this author explained in her paper in Analytical Chemistry that carbon was often added to iron gall ink and its presence in the ink of the Vinland Map is not proof that the Map ink is not an iron gall ink [13]. Carbon was added to iron gall ink as a colorant in the medieval period. This was done to enable the user to see the location of the inked line before the color of the iron tannate had developed. Carbon has also been reported in the ink of the Tartar Relation which is acknowledged to be an iron gall ink. There is no conclusive evidence that the ink of the Vinland Map is a carbon ink based on the identification of carbon in the ink.

Soon after Walter McCrone published the results of his analysis of the Vinland Map ink and his statement that the Vinland Map is a forgery based on the presence of anatase in the ink, this author corresponded with him with regard to the medium that was used to suspend the anatase and to prepare an ink. In an early reply, Dr. McCrone stated that he had identified an alkyd resin in the ink but later he retracted that. In 1991, he visited the Beinecke to again sample the ink for analysis using infra-red spectroscopy. He reported the presence of gelatin in the sample he had taken [14]. As this author has reported, gelatin could be present as a product that resulted from the hydrolysis of the parchment of the Map [13]. The use of gelatin as a medium for suspension of anatase for the preparation of an ink has not been investigated and raises the question of how much of the discussion of anatase as evidence of a forgery is based on a full understanding of the nature of an ink that could actually be used to write.

As the title of this paper identifies, there is further research needed to confirm whether or not the ink of the Vinland Map is an iron ink, a carbon ink, or an ink made using anatase and gelatin. One other analysis of the ink that could be investigated would be to determine whether or not the organic component of an iron gall ink is present. In the 1971 Newbury Library publication of the Proceedings of the Smithsonian Vinland Map Conference that was held in 1966, there is a reference to this author's publication regarding “The Vinland Map-A Case Study." This paper reviewed was what known at the time of the physical condition of the Vinland Map and discussed potential methods in use at the time for the analysis of iron gall inks [15]. These include chromatography and other analytical methods none of which have been used with regard to the ink of the Vinland Map.

The suggestion of forgery brought about by the McCrone identification of anatase in the ink of the Map captured the attention of most scholars until Thomas Cahill et al. published the results of their PIXE analysis of the Vinland Map ink in a paper in Analytical Chemistry in 1987. These authors presented data that were interpreted as showing that the concentration of titanium in the ink was such that the anatase that is present could only be present in trace amounts. This would suggest that the anatase was not purposely added to the ink. In McCrone's 1988 paper, his reference 6 is to a communication this author shared with McCrone. This personal communication from this author to McCrone suggested that as anatase is formed from ilmenite by treatement with sulfuric acid, the anatase present in the Vinland Map ink could have been formed from ilmenite in the ink. The presence of titanium in other medieval inks suggests that the presence of ilmenite in medieval inks is a realistic possibility. Further investigations of medieval inks to determine the nature of a titanium containing compound or compounds is required in order to correctly resolve this matter [16].

The question of whether the ink of the Vinland Map is an iron gall ink has been put forward as relevant to whether ilmenite could have been the source of the anatase in the Map ink. I would suggest that a new interprettation of the ultraviolet fluorescence results obtained in the British Museum Research Laboratory and the presence of goethite in the particles from the crease of the Map, provide reasons for reconsideration of the Map ink as an iron gall ink. Further examination of the Map under ultraviolet could be useful.

I would also suggest that analyses of other medieval inks that contain titanium to determine in what form the titanium is present need to be carried out before conclusions regarding the authenticity of the Vinland Map are considered. This last research effort is the one that is probably most easily undertaken following along the lines of analyses that were conducted on the Vinland Map ink. It would be reasonable to suggest that documents analyzed by earlier researchers and determined to have inks that contain titanium could be analyzed to determine in what form the titanium is present. A project of this nature would require funding but the methods for analysis are available.

\section{Radiocarbon Date of Vinland Map Parchment}

It is useful to point out here for readers who are not fa- 
miliar with the literature about the Vinland Map that the parchment of the Map has been securely dated to the 15th century by radiocarbon dating [17]. Subsequent to the conclusion of forgery based on the presence of anatase in the ink, the radiocarbon dating of the parchment was recognized as being able to show whether a date would confirm the 20th century origin of the Map or whether it would be a 15th century date and would continue to support the need for further investigation of the ink. The latter is the case. However, papers published subsequent to the publication of the 15th century date in 2002 have taken a simplified approach and merely claimed that a forger used a 15th century piece of parchment. A detailed explanation of the means by which the forger obtained the piece of parchment is needed. This must include how the Map was eventually included in the volume now proposed as the location of the Map for a long enough period of time to produce wormholes consistent with being bound with other 15th century documents. Further consideration of the 15th century date of the parchment is important and supports the call for certain forms of further investigation of the Vinland Map and the medieval documents with which it was at one time bound.

\section{Recommendations for Further Research}

A complete study of the three documents involved, Vinland Map, Speculum Historiale and Tartar Relation, has been carried out and reported by Rene Larsen and Dorte V. P. Sommer [18,19]. These authors also recommend further experiments, in this case for the determination of whether the three manuscripts had been bound together in the 15th century. In this regard, it is important to note the significance of the discovery by Gregory Guzman of a copy of the Tartar Relation and of the Speculum Historiale that were bound together in the 14th century [20].

The technical studies that have been carried out to date on the Vinland Map have provided a basis for further consideration of the questions that need to be addressed. The task is by no means completed and the value of further studies is important to recognize. The absence of iron in large concentrations in the ink throughout the Vinland Map is important to explain. In preparing anatase from ilmenite in 1974 to demonstrate the possibility that the anatase in the ink of the Vinland Map could have originated in some manner from ilmenite in the ink, I assumed an iron gall ink. The following comment regarding my proposal that the anatase in the Vinland Map ink could be present naturally and not be a forger's addition is entirely appropriate with regard to iron. The reference to anatase in the comment should be prefaced by stating that the evidence does show that the titanium is concentrated in the ink $[9,21]$. Suggestions that the ana- tase is over the entire surface of the Map parchment have not been confirmed.

"Examination of her (JSO) anatase by a colleague, mineralogist Dr. Kenneth Towe, showed that it was very different from the neat, rounded crystals found in the Vinland Map and modern pigments, and despite decades of further work, she was also never able to explain how the iron would have disappeared from the Vinland Map ink” [22].

I propose that consideration be given to the explanations presented in this paper regarding the absence of large concentrations of iron in some areas of the Vinland Map ink. Also, as I stated in 2000, further studies of titanium containing compounds in medieval inks should be undertaken to pursue an understanding of the source of the anatase in the Vinland Map ink [15]. In addition, I propose that the $\mathrm{x}$-ray diffraction pattern of the anatase in the Vinland Map ink be published. This could provide data for evaluation of the rounded crystals of anatase in the ink.

Another area in need of further research relates to the fact that the origin of the Vinland Map remains unresolved. A paper in press in Pre-Columbiana provides observations regarding that matter by Thomas E. Marston written prior to his death in 1984 [23]. Further research is needed regarding the provenance of the Vinland Map and the documents that are proposed to have been bound with it in the 15th century.

\section{REFERENCES}

[1] R. A. Skelton, T. E. Marston and G. D. Painter, "The Vinland Map and the Tartar Relation,” Yale University Press, New Haven, 1965, 1995.

[2] A. D. Baynes-Cope, "The Scientific Examination of the Vinland Map at the Research Laboratory of the British Museum," The Geographical Journal, Vol. 140, No. 2, 1974, pp. 208-211. doi:10.2307/1797077

[3] K.M. Towe, “The Vinland Map Ink Is NOT Medieval," Analytical Chemistry, Vol. 76, No. 3, 2004, pp. 863-865.

[4] J. H. McCulloch, "The Vinland Map-Some 'Finer Points' of the Debate," 2005. www.econ.ohio-state.edu/jhm/arch/vinland/vinland.htm

[5] D. McNaughton, "A World in Transition: Early Cartography of the North Atlantic," Vikings: The North Atlantic Saga, Smithsonian Institution Press, Washington DC, 2000, p. 266.

[6] K. T. Knox and R. L. Easton Jr., "Recovery of Lost Writings on Historical Manuscripts with Ultraviolet Illumination,” Chester F. Carlson Center for Imaging Science, Rochester Institute of Technology, Rochester, 2003, p. 3.

[7] W. C. McCrone, "Chemical Analytical Study of the Vinland Map,” Yale University Library, New Haven, 1974.

[8] D. Andreeva, I. Mitov, T. Tabakova and A. Andreeva, "Formation of Goethite by Oxidative Hydrolysis of Iron (II) Sulphate,” Journal of Materials Science: Materials in 
Electronics, Vol. 5, No. 3, 1994, pp. 168-172.

[9] T. A. Cahill, R. N. Schwab, B. J. Kusko, R. A. Eldred, G. Moller, D. Dutschke, D. L. Wick and A. S. Pooley, "The Vinland Map, Revisited: New Compositional Evidence on Its Inks and Parchment," Analytical Chemistry, Vol. 59, No. 6, 1987, pp. 829-833. doi:10.1021/ac00133a009

[10] T. A. Cahill and H. K. Bruce, "Compositional and Structural Studies of the Vinland Map and Tartar Relation,” In: R. A. Skelton, T. E. Marston and G. D. Painter, Eds., The Vinland Map and the Tartar Relation: New Edition, Yale University Press, New Haven, 1995.

[11] W. C. McCrone, “The Vinland Map: Table III,” Analytical Chemistry, Vol. 60, 1988, pp. 1009-1018.

[12] K. L. Brown and R. J. H. Clark, “Analysis of Pigmentary Materials on the Vinland Map and Tartar Relation by Raman Microprobe Spectroscopy," Analytical Chemistry, Vol. 74, No. 15, 2002, pp. 3658-3661.

[13] J. S. Olin, "Evidence That the Vinland Map is Medieval," Analytical Chemistry, Vol. 75, No. 23, 2003, pp. 67456747.

[14] W. C. McCrone, "Vinland Map 1999," Microscope, Vol. 47, No. 2, 1999, pp. 71-74.

[15] J. S. Olin, "The Vinland Map-A Case Study," Proceedings of the 1st Georgetown University Conference on Surface Analysis, Georgetown University Law Center, Wa- shington DC, 1970, pp. 25-39.

[16] J. S. Olin, "Without Comparative Studies of Inks, What
Do We Know about the Vinland Map?” Pre-Columbiana, Vol. 2, No. 1, 2000, pp. 27-36.

[17] D. J. Donahue, J. S. Olin and G. Harbottle, "Determination of the Radiocarbon Age of Parchment of the Vinland Map,” Radiocarbon, Vol. 44, No. 1, 2002, pp. 45-52.

[18] R. Larsen, D. V. P. Sommer and M. Vest, “Assessment and Survey of the Vinland Map and the Tartar Relation and Speculum Historiale,” Zeitschrift fur Kunsttechnologie and Konservierung, Vol. 20, No. 2, 2006, pp. 249260.

[19] R. Larsen and D. V. P. Sommer, "Facts and Myths about the Vinland Map and Its Context," The 23rd Conference on the History of Cartography, Copenhagen, 12-17 July 2009, in Press.

[20] G. G. Guzman, "The Vinland Map Controversy and the Discovery of a Second Version of the Tartar Relation: The Authenticity of the 1339 Text," Terrae Incognitae, Vol. 38, 2006, pp. 19-25. doi:10.1179/008228806790802037

[21] K. M. Towe, “The Vinland Map: Still a Forgery,” Accounts of Chemical Research, Vol. 23, No. 3, 1990, pp. 84-87. doi:10.1021/ar00171a005

[22] en.wikipedia.org/wiki/Vinland_map

[23] J. S. Olin, "The Vinland Map: Observations by Thomas E. Marston Relating to the Council of Basle, 1431=1449," Pre-Columbiana: A Journal of Long Distance Contacts, 2008-2010, in Press. 